Annals of Warsaw University of Life Sciences - SGGW

Land Reclamation No 47 (2), 2015: 91-101

(Ann. Warsaw Univ. Life Sci. - SGGW, Land Reclam. 47 (2), 2015)

\title{
Concept of hybrid embankment
}

\author{
MASAHARU FUKUE ${ }^{1}$, ZBIGNIEW LECHOWICZ ${ }^{2}$, RIE TAKAHASHI ${ }^{3}$, \\ KOUJI UEHARA ${ }^{4}$ \\ ${ }^{1}$ Tokai University, Japan \\ ${ }^{2}$ Department of Geotechnical Engineering, Warsaw University of Life Sciences - SGGW, Poland \\ ${ }^{3}$ Japanese Geotechnical Association for Housing Disaster Prevention, Japan \\ ${ }^{4}$ Life Engineering Co., Japan
}

\begin{abstract}
Concept of hybrid embankment. An innovative technique which is similar to a natural process, i.e., biogeochemical (carbonate) diagenesis, is proposed to construct a hybrid embankment. In this study, the hybrid embankment is defined as a soil embankment which has a microbially induced framework structure of sand sheets and columns in the soft soil matrix. The sand materials are cemented with magnesium-calcite or dolomite, induced by ureolytic microbes. To design and construct hybrid embankments, fundamental problems, such as feasibility in terms of stability, geoenvironmental engineering practices, etc., are examined and discussed. It was shown that the hybrid embankment can be environmentally friendly and also can contribute solving technical and financial problems encountered in actual practice.
\end{abstract}

Key words: embankment, soft soils, sand sheets, sand columns, bio-cement

\section{INTRODUCTION}

Soil improvement can be used to mitigate inadequate slope stability for both new and existing embankments, as well as reduce settlement. The primary ground improvement techniques to mitigate slope stability fall into two general categories, namely densification and altering the soil composition (WSDOT Geotechnical Design Manual M 46-03.08 October 2013).
Soil improvement is used to address a wide range of geotechnical engineering problems, including, but not limited to, the following (WSDOT Geotechnical Design Manual M 46-03.08 October 2013):

- improvement of soft or loose soil to reduce settlement, increase bearing resistance, and/or to improve overall stability for structure and wall foundations and/or for embankments;

- to mitigate liquefiable soils;

- to improve slope stability for landslide mitigation;

- to retain otherwise unstable soils;

- to improve workability and usability of fill materials;

- to promote settlement and soil shear strength gain.

To satisfy the above requirements, the microbial cement techniques are being examined. In this paper, the slope stability improvement of embankment is mainly discussed.

The microbial cement technique uses the formation mechanism of sedimentary rocks which is mineralogical cementation. As well known, a typical binder for sedimentary rock is carbonate 
(Moore 2001). Most carbonate diagenesis is in the category of the bio-cementation process, which is well known as the formation of limestone. In fact, any marine sediment contains some carbonate, which is used in the carbonate diagenesis (Fukue et al. 1999). This suggests that soils can be strengthened by precipitating carbonate, regardless of natural or artificial processes.

There are many species of microbes which can induce the precipitation of carbonate (De Muyncka et al. 2010). The processes of carbonate precipitation are basically dependent on the degradation of organic matter by microbes, and the consequent production of $\mathrm{CO}_{2}$, under the presence of $\mathrm{Ca}^{2+}$. However, it needs the necessary or sufficient conditions for the production of carbonate, which is dependent on many factors, such as the species and concentration of microbe, the type and concentration of reactive metal ions, the type of organic matter, $\mathrm{pH}$, temperature, etc.

Some species of microbes have been examined for the production of carbonate, usually calcium carbonate (De Muyncka et al. 2010). Recently, many researchers have selected Sporosarcina (Bacillus) pasteurii, as the most favorite microbe, because of strong urease activity (Bang et al. 2001, Ferris et al. 2003, DeJong et al. 2006, Whiffin et al. 2007).

To obtain a large amount of carbonate precipitation, Reaction (1) can be utilized. Since calcite (calcium carbonate) may be unstable with changes in $\mathrm{pH}$ and partial pressure of $\mathrm{CO}_{2}$, other types of carbonate can be favored. In this study, magnesium-calcite or dolomite is recommended to obtain more stable structures of soil. To achieve this, the urease enzyme produced by ureolytic microbes can be used to induce hydrolysis of urea $\left(\left(\mathrm{NH}_{2}\right)_{2} \mathrm{CO}\right)$, as follows:

$\left(\mathrm{NH}_{2}\right)_{2} \mathrm{CO}+2 \mathrm{H}_{2} \mathrm{O} \rightarrow \mathrm{CO}_{3}{ }^{2-}+2 \mathrm{NH}_{4}^{+}$

$\mathrm{Ca}^{2+}+\mathrm{CO}_{3}^{2-} \rightarrow \mathrm{CaCO}_{3} \downarrow$

$1 / 2 \mathrm{Ca}^{2+}+1 / 2 \mathrm{Mg}^{2+}+\mathrm{CO}_{3}{ }^{2-} \rightarrow 1 / 2 \mathrm{CaMg}\left(\mathrm{CO}_{3}\right)$

This study tries to produce $\mathrm{CaMg}\left(\mathrm{CO}_{3}\right)_{2}$ in Reaction (3) instead of $\mathrm{CaCO}_{3}$ in Reaction (2), because the $\mathrm{Mg}$-calcite or dolomite is more tolerant to acid than calcite (Fukue et al. 1999).

Since carbonate can play an important role as a binder of soil, the content of carbonate becomes one of the most important factors to evaluate the mechanical properties of soils cemented in natural or artificial process (Fukue et al. 1999, 2011). In this study, the averaged carbonate content of soil $(C)$ is defined by

$$
C=\frac{m_{C a}}{m_{s}+m_{C a}} \times 100[\%]
$$

where:

$m_{C a}$ - mass of carbonate precipitated; $m_{s}$ - dry mass including natural carbonate. 


\section{EXPERIMENTATION}

\section{Materials}

A strong ureolytic microbe (NO-A10) was isolated from Japanese soil. Using the microbes, sandy soils were improved by the microbially induced calcite $\left(\mathrm{CaCO}_{3}\right), \mathrm{Mg}$-calcite and possibly dolomite $\left(\mathrm{CaMg}\left(\mathrm{CO}_{3}\right)_{2}\right)$ (Fukue et al. 2011). The microbe isolated is Sporosarcina sp., facultative bacteria, Gram-positive and an alkalophilic. The bacteria have a diameter of approximately $1 \mu \mathrm{m}$ and a length of a few micrometers. NO-A10 can produce urease very fast. As a result, $1 \mathrm{M}$ calcium carbonate can be induced within $2 \mathrm{~h}$ at $28^{\circ} \mathrm{C}$. The rate is probably the record of microbial carbonate precipitation. The dolomite like mineral showed a better binder effect for improvement (Fukue et al. 2011).

\section{Experimental Procedures}

The ureolytic strains, NO-A10 were cultivated using the culture medium $\mathrm{F}$ which is under development. It is noted that the alkalophilic NO-A10 strain should be cultivated at a $\mathrm{pH}$ higher than 7.0. After the cultivation began, about 4 days are needed until the strains produce urease at a temperature of $20^{\circ} \mathrm{C}$ but are faster at a higher temperature.

Prior to the injection, the cultivated solution (B-solution) was mixed with the reactive chemical solution (R-solution) which consists of $0.7 \mathrm{M} \mathrm{CaCl}_{2}$, $0.7 \mathrm{M} \mathrm{MgCl}_{2}$, and $1.4 \mathrm{M}\left(\mathrm{NH}_{2}\right)_{2} \mathrm{CO}$.
The mixed solution of pore volume was sprayed on sand materials loosely compacted in a box. The drainage was allowed from the bottom of the box. The intensity of solidification, i.e., cementation, was measured with a pocket penetrometer (Soil Test Co.).

\section{RESULTS AND DISCUSSION}

\section{Compressive strength}

If the carbonate content of soil (excluding rock) is less than $10 \%$, the unconfined compressive strength can be expressed by

$$
q_{u}=R_{i} C
$$

where:

$q_{u}$ - unconfined compressive strength of soil;

$R_{i}$ - increasing rate of $q_{u}$ due to the carbonate produced.

The results obtained for the first injection are shown in Figure 1. The measurements of the pocket penetrometer scatter from 25 to $450 \mathrm{kPa}$ depending on the carbonate content, as shown in Figure 1. Nevertheless, the concept of unconfined compressive strength is still applicable under this condition. The scattering is mainly due to the distribution of microbes in the sand materials. One could stand on the specimen without the collapse and settlement of sand.

Though the data are insufficient, the $q_{u}$ estimated from the measurements of the pocket penetrometer may approximately be expressed by 


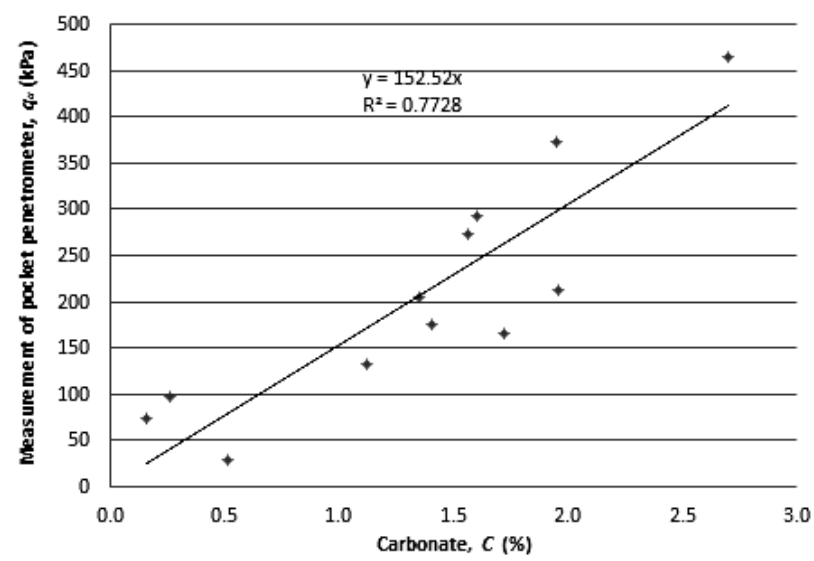

FIGURE 1. Measurements of pocket penetrometer versus carbonate content for cemented sand

$$
q_{u}=R_{i} C=150 C[\mathrm{kPa}]
$$

where:

$R_{i}=150 \mathrm{kPa} /$ carbonate [\%].

\section{CONSTRUCTION PRACTICE}

In the case of organic soils as foundation soil and fill, most of the conventional techniques cannot be applied, because of very high compressibility and very low strength. For the application, some technologies, such as soil replacement with vibroflotation, deep piles, DSM soil

improvement, are introduced (Wojtasik et al. 2006). To assure the safety of the embankment, a hybrid embankment which consists of bone structures using sand sheets and columns is considered.

This study examines that the microbial cement technique can mitigate instability slope stability and settlement. The embankment consisting of the cemented soil structure and organic soil is defined as a hybrid embankment. Hybrid embankment is illustrated in Figure 2. It may be important to protect the slopes from erosion.

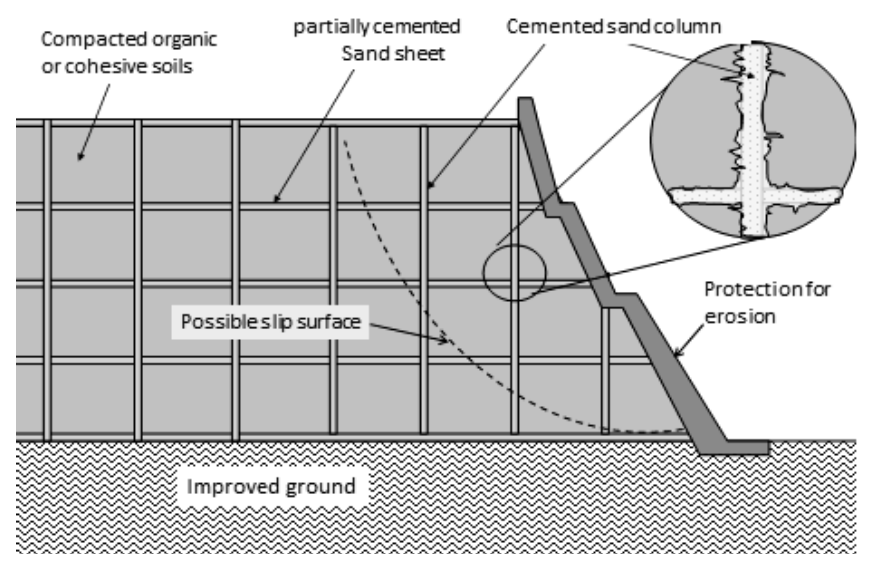

FIGURE 2. A schematic of hybrid embankment using cemented sand sheets and columns (not to scale) 


\section{SLOPE STABILITY}

\section{Circular slip analysis}

As a circular slip surface is usually assumed for the stability problem of embankment, common slice analysis for a circular slip was used to compare safety factors at different heights of embankment, as shown in Figure 3. The conditions for the analyses are also indicated in Figure 3.
To reach the critical condition $\left(F_{S}=1.0\right)$ for the higher embankment $(\mathrm{H}=10 \mathrm{~m})$, the average undrained shear strength should be expressed by the driving force divided by the slip length, i.e., $321.5 / 15.7=20.5 \mathrm{kPa}$. Since the original undrained shear strength is $15 \mathrm{kPa}$, the gain of $5.5 \mathrm{kPa}$ per length is needed.

If sand sheets and columns which will be cemented with microbial precipitation of carbonate are installed, the

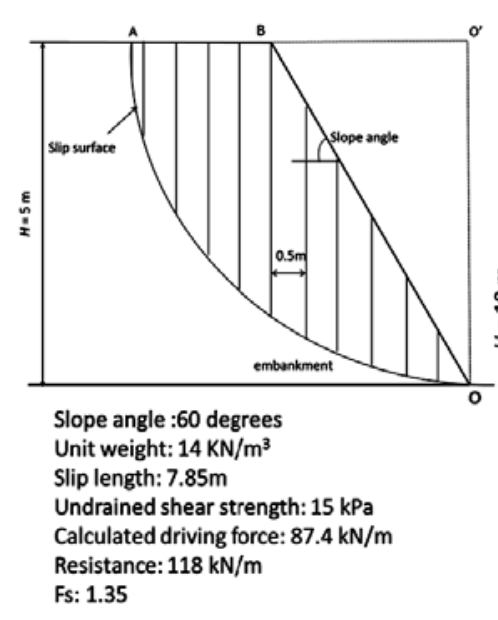

a) A circular slip for a height of $5 \mathrm{~m}$

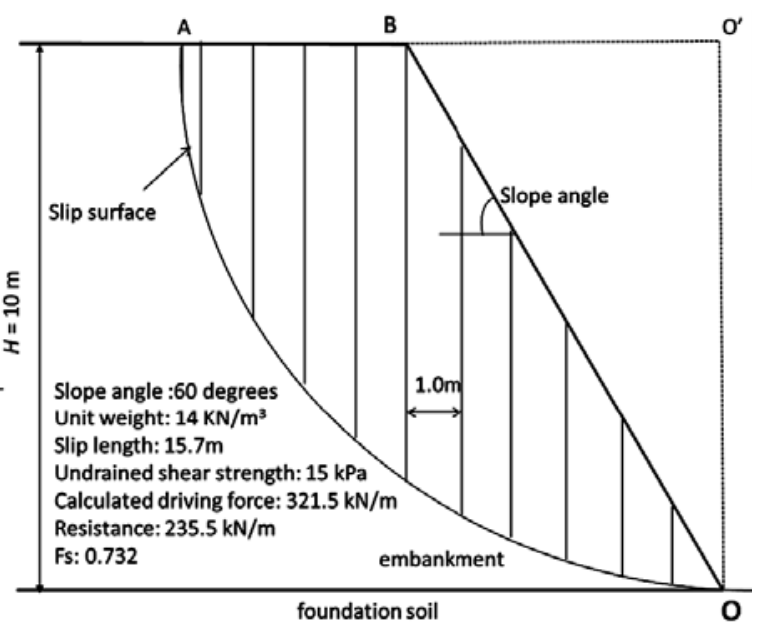

b) A circular slip for a height of $10 \mathrm{~m}$

FIGURE 3. A comparison between safety factors for different heights of embankment under similar conditions (not to scale)

The results showed that the safety factor at a height of $5 \mathrm{~m}$ is 1.35 for the very low undrained shear strength, while it was 0.732 at a height of $10 \mathrm{~m}$. This means that the embankment at a height of $5 \mathrm{~m}$ is stable for the assumed slip, but it is unstable without support at a height of $10 \mathrm{~m}$, thus a technology to embank using such soft materials is required. resultant (average) shear strength $\left(\tau_{f}\right)$ and the replacement ratio $(r)$ along the slip surface is given by

$$
\begin{gathered}
\tau_{f \text { mat }}(1-r)+\tau_{\text {fsand }} r=\tau_{f}[\mathrm{kPa}] \\
r=\frac{\tau_{f}-\tau_{\text {fmat }}}{\tau_{\text {fsand }}-\tau_{\text {fmat }}}
\end{gathered}
$$


where:

$\tau_{\text {fmat }}-$ shear strength of soil matrix;

$\tau_{\text {fand }}-$ shear strength of sand sheets and columns which consist of cementation and frictional resistance;

$\tau_{f} \quad-$ resultant (averaged) shear strength on the assumed slip surface;

$r$ - ratio of area occupied by cemented sand sheets and columns to the slip surface.

Assuming that $\tau_{\text {fmat }}$ is $15 \mathrm{kPa}$ (very soft soil) and the $\tau_{\text {fsand }}$ is $90 \mathrm{kPa}$ (usual for microbially cemented sand), the
Effects on slope stability with seismic force

The slope stability of embankment is usually examined by the circular slip analysis. However, this study focusses on the effects of bone structure for a hybrid embankment. Therefore, the effects are examined on a plane slip surface, as shown in Figure 4.

In Figure $4 \mathrm{a}$, the driving (sliding) force $-T_{\max }$ can be expressed using horizontal seismic coefficient $-K$, as

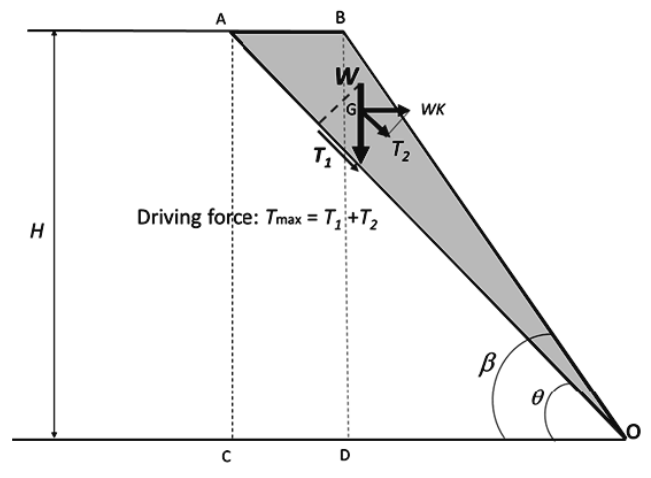

a) Sliding forces

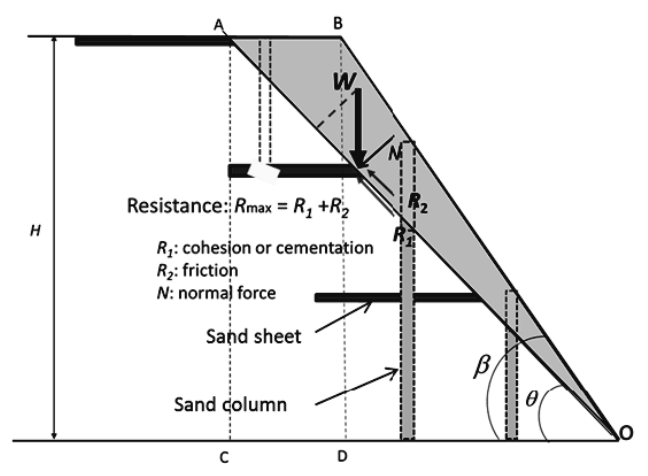

b) Resistant forces

FIGURE 4. A simple slope stability problem assuming a plain slip surface for simple comparison of safety factors with and without a sand sheets and column

replacement ratio $r$ to reach the critical resultant shear strength, i.e. $20.5 \mathrm{kPa}$, is estimated as $7.3 \%$. Note that the result varies by changing the position of the center of circle and the radius of circle, in Figure 3. This means that Figure 3 may not provide the minimum safety factors.

$$
T_{\max }=W \sin \theta+W K \cos \theta
$$

where:

$W$ - weight of the sliding wedge of soil;

$\theta$ - angle between the slip surface and the horizon.

On the other hand, the resistance force $\left(R_{\max }\right)$ is given by the cohesion and 
frictional components, as shown in Figure $4 b$, as

$$
R_{\text {max }}=R_{1}+R_{2}=c L+N \tan \phi
$$

where:

$c$ - averaged cohesion of the slip plane;

$L-$ area of the slip line AO times unit width;

$N$ - normal force acting on the slip plane; $\phi$ - frictional angle.

In fact, the $c$ consists of two components, i.e. cohesion of the soil matrix and the cementation of sand sheets and columns due to the microbial cement techniques. The $\phi$ may be different from that of sand, but dense and cemented sand.

The safety factor $\left(F_{s}\right)$ is given by

$$
F_{S}=\frac{R_{\max }}{T_{\max }}=\frac{c L+N \tan \phi}{W \sin \theta+W K \sin \theta}
$$

where:

$$
W=W_{1}+W_{2}=\left(1-\frac{r}{100}\right) \gamma_{1} A+\frac{r}{100} \gamma_{2} A
$$

$\mathrm{A}=\left\{\tan \left(90^{\circ}-\theta\right)-\tan \left(90^{\circ}-\beta\right)\right\} \frac{H^{2}}{2}$

$N=W_{2} \cos \theta=\frac{r}{100} \gamma_{2} A \cos \theta$

$R_{\text {max }}=\left\{\left(1-\frac{r}{100}\right) c_{\text {mat }} L+\frac{r}{100} c_{\text {sand }} L\right\} \sin \theta+$ $+N \tan \phi$

$L=\frac{H}{\sin \theta}, K=\frac{K_{h}}{3}, K_{h}=\frac{\alpha_{\max }}{g}$ where:

$\alpha_{\max }$ - horizontal maximum acceleration;

$r$ - ratio of replacement;

$\gamma_{1}$ - unit weight of soil matrix;

$\gamma_{2}$ - unit weight of sand sheet and column;

$H$ - height of embankment.

\section{Examples of calculation}

Examples of the simple calculation are shown in terms of safety factor $-F_{S}$ (see Tables 1 and 2). Table 1 presents the parameters and constant used for the calculation and Table 2 shows the results of calculations. For example, the cohesion of the soil matrix (organic or clayey soil) was assumed to be $15 \mathrm{kPa}$ (Table 2) and the frictional resistance is neglected. On the other hand, the cohesion of cemented sand sheets and columns was assumed as $70 \mathrm{kPa}$, which is approximately one third of the $q_{u}$ for a carbonate content of $1.5 \%$. The angle of friction for relatively dense and cemented sand is 40 degrees, which can be deduced based on the triaxial compression test.

TABLE 1. Assumed and measured parameters and a constant for calculation

\begin{tabular}{|c|rl|}
\hline$\alpha_{\max }$ & 2000 & gal $\left(=\mathrm{cm} / \mathrm{s}^{2}\right)$ \\
$\beta$ & 60 & Degrees \\
$\theta$ & 45 & Degrees \\
$\phi$ & 40 & Degrees \\
$g$ & 980 & $\mathrm{gal}\left(=\mathrm{cm} / \mathrm{s}^{2}\right)$ \\
$\gamma_{1}$ & 14 & $\mathrm{kN} / \mathrm{m}^{3}$ \\
$\gamma_{2}$ & 18 & $\mathrm{kN} / \mathrm{m}^{3}$ \\
$H$ & 5 & $\mathrm{~m}$ \\
\hline
\end{tabular}


TABLE 2. Safety factors for slope stability analyses with or without cemented sand sheets and columns

\begin{tabular}{|c|c|c|c|c|c|c|c|c|c|c|c|c|c|}
\hline case & $\begin{array}{c}\text { ratio, } r \\
{[\%]}\end{array}$ & $\begin{array}{c}c_{\text {mat }} \\
{[\mathrm{kPa}]}\end{array}$ & $\begin{array}{c}c_{\text {sand }} \\
{[\mathrm{kPa}]}\end{array}$ & $\begin{array}{c}W_{1} \\
{[\mathrm{kN} / \mathrm{m}]}\end{array}$ & $\begin{array}{c}W_{2} \\
{[\mathrm{kN} / \mathrm{m}]}\end{array}$ & $\begin{array}{c}W \\
{[\mathrm{kN} / \mathrm{m}]}\end{array}$ & $\begin{array}{c}T_{1} \\
{[\mathrm{kN} / \mathrm{m}]}\end{array}$ & $\begin{array}{c}T_{2} \\
{[\mathrm{kN} / \mathrm{m}]}\end{array}$ & $\begin{array}{c}T \\
{[\mathrm{kN} / \mathrm{m}]}\end{array}$ & $\begin{array}{c}R_{1} \\
{[\mathrm{kN} / \mathrm{m}]}\end{array}$ & $\begin{array}{c}R_{2} \\
{[\mathrm{kN} / \mathrm{m}]}\end{array}$ & $\begin{array}{c}R \\
{[\mathrm{kNN} / \mathrm{m}]}\end{array}$ & $F_{S}$ \\
\hline 1 & 0.0 & 15.0 & 0.0 & 115.1 & 0.0 & 115.1 & 72.4 & 60.8 & 133.3 & 119.2 & 0.0 & 119.2 & 0.89 \\
\hline 2 & 5.0 & 15.0 & 70.0 & 109.3 & 7.4 & 116.7 & 68.8 & 61.7 & 135.2 & 141.0 & 38.3 & 179.4 & 1.33 \\
\hline 3 & 7.0 & 15.0 & 70.0 & 107.0 & 10.4 & 117.4 & 67.3 & 62.1 & 135.9 & 149.8 & 53.7 & 203.4 & 1.50 \\
\hline
\end{tabular}

Case 1 indicates that the $F_{S}$ is only 0.89 , because of no cemented sand sheets and columns with horizontal seismic force. The effect of the increased number of cemented sand sheets and columns is shown by the ratio of replacement, $r$ value, in this study. The $r$ value indicates the ratio of area occupied by cemented sand sheets and columns across the slip surface. A five percent of $r$ value (case 2) increased $F_{S}$ up to 1.33 , as shown in Table 2. At a $r$ of $7 \%$ (case 3 ), the $F_{S}$ is 1.50 .

It is noted that the effects of settlement of the foundation soils and embankment itself have to be taken into account for the stability analyses. The consolidation of the soil matrix is also important, because of not only the settlement of embankment, but also negative friction to the cemented sand sheets and columns. It is more realistic to allow the vertical settlement of the soil matrix. For one of the solutions, the depression of the top surface can be regularly filled with proper materials.

\section{INSTALLMENT OF SAND AND ITS} SOLIDIFICATION

\section{Sand sheet}

Sand sheets can be made by laying sand materials on the embankment with a certain height (Fig. 2). The sheets can be partially or totally cemented with microbial precipitation of carbonate. As the cemented sand sheet is porous, which have a high permeability, the consolidation of the embankment can be promoted. The surface of the sand sheet enables the trafficability of construction vehicles during embanking works. Consequently, a high embankment can be constructed. The aim of the installation of sand sheets is mainly to add the structural strength of the embankment during and after the construction works.

\section{Sand column}

To build framework structure of embankment, the sand columns can be installed through the sand sheets and soil matrix using the machine for sand compaction, as shown in Figure 5. The installation of the column can be made after a sand 


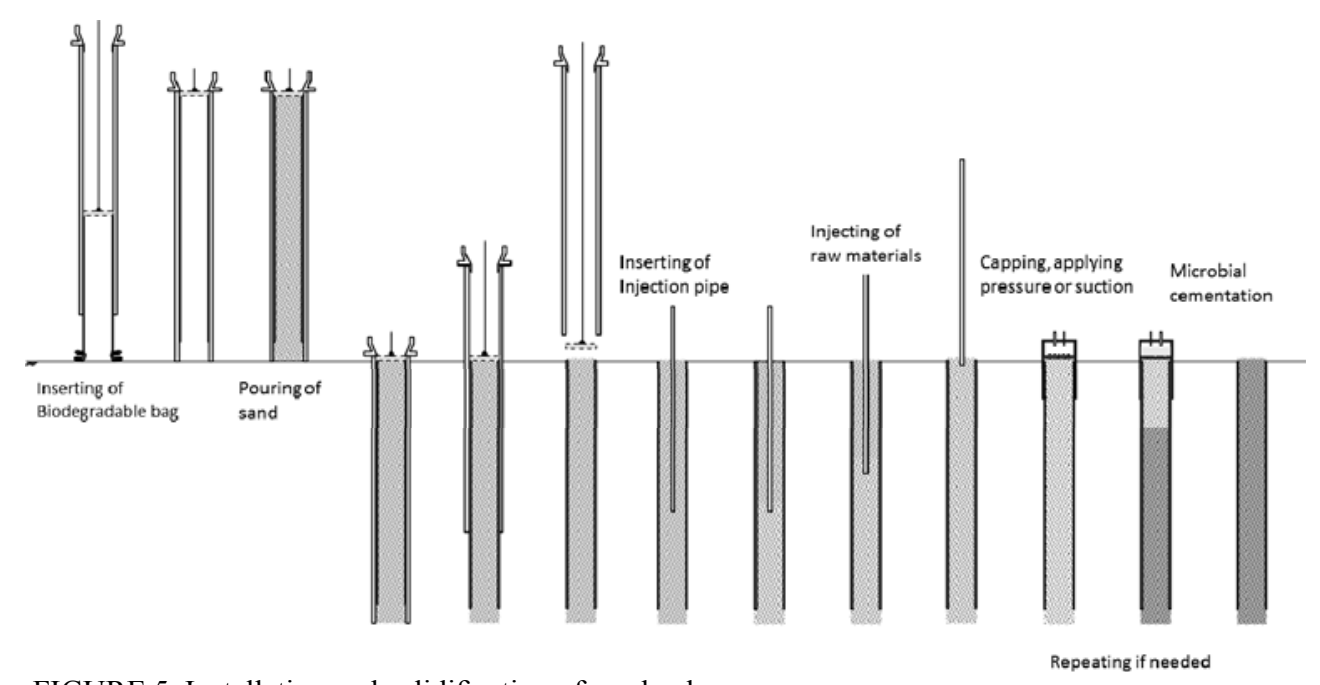

FIGURE 5. Installation and solidification of sand column

sheet was laid at a given height. The aim of the installation is not dissimilar to the sand sheet described above.

The procedures of installation of sand columns and solidification procedures are as follows:

1) inserting the biodegradable bag into the duct (left in Fig. 5) on the ground;

2) pouring sand materials in the biodegradable bag;

3) penetrating the duct with sand materials;

4) pulling up the duct only, and removing the duct;

5) spreading the sand cap on the ground as the weight for consolidation of soil matrix (if it is needed);

6) leaving until the settlement of embankment is allowable;

7) inserting an injection pipe for the mixed solution;

8) injecting the mixed solution during the pulling up of the injection pipe;

9) removal of the injection pipe;
10) capping, and applying pressure and suction (if needed);

11) spreading subgrade soil.

The biodegradable bag indicated for the procedure 1 , which is also indicated the left in Figure 5, may not be required if the strength of the matrix is sufficient.

\section{CONCLUSIONS}

This study examined slope stability of a hybrid embankment which can be constructed using organic soils and sand sheets and columns. The feature of this technique is that the sand sheets and columns are cemented with carbonate induced by microbes. The results from calculation showed that the cemented sheets and columns strongly contribute the increase in slope stability. It is concluded that hybrid embankment can be:

a) used in which the soil materials are very poor and a high embankment is needed; 
b) used against additional forces, e.g. a very high horizontal acceleration during an earthquake;

c) economical, because of low total life cycle cost (create soil (carbonate) particles);

d) environmentally friendly, because of biological cement (carbonate).

The technique proposed enables use of poor soil materials. However, the stability of the foundations, construction methods, negative friction to the sand columns due to the consolidation of the soil matrix and settlement for both the foundation soils and embankment itself should be examined.

\section{Acknowledgments}

This study was partially supported by Kakenhi (22560498), Japan Society for the Promotion of Science (JSPS). The authors thank Prof. C.N. Mulligan, Concordia University, for her great help during the study.

\section{REFERENCES}

BANG S.S., GALINAT J.K., RAMAKRISHNAN V. 2001: Calcite precipitation induced by polyurethane-immobilized Bacillus pasteurii. Enzyme and Microbial Technology 28, 404-409.

DeJONG J.T., FRITZGES M.B., NÜSSLEIN K. 2006: Microbially induced cementation tp control sand response to undrained shear. Journal of Geotechnical and Geoenvironmental Engineering, ASCE, 1381-1392.

De MUYNCKA W., De BELIEA N., VERSTRAETE W. 2010: Microbial carbonate precipitation in construction materials: A review. Ecological Engineering 36, 118-136.
FERRIS F. G., PHOENIX V., FUJITA Y., SMITH R.W. 2003: Kinetics of calcite precipitation induced by ureolytic bacteria at 10 to $20^{\circ} \mathrm{C}$ in artificial groundwater. Geochimica et Cosmochimica Acta 67 (8) 1701-1722.

FUKUE M., NAKAMURA T., KATO Y. 1999: Cementation of soils due to calcium carbonate. Soils and Foundations 39 (6), 55-64.

FUKUE M., ONO S., SATO Y. 2011: Cementation of sands due to Microbiologically-induced Carbonate. Soils and Foundations 51 (1), 83-93.

MOORE C.H. 2001: Carbonate Reservoirs, Porosity Evolution and Diagenesis in a Sequence Stratigraphic Framework. Elsevier.

WHIFFIN V.S., van PAASSEN L.A., HARKES M.P. 2007: Microbial carbonate precipitation as a soil improvement technique. Geomicrobiology Journal 24, 417-423.

WOJTASIK A.T., ŁECKI P., TROC M., DOZY P. 2006. Geotechnical conditions and soil improvement techniques applied in construction of the A2 motorway in Poland, http://www. gtprojekt.pl/wp-content/uploads/2013/01/ Problematic-soils_KL_article_23.10.2006. pdf.

WSDOT Geotechnical Design Manual, 2013. [on-line source]. http://www.wsdot.wa.gov/ publications/manuals/fulltext/m46-03/chapter9.pdf, http://www.wsdot.wa.gov/publications/manuals/fulltext/m46-03/chapter11.pdf.

Streszczenie: Koncepcja nasypu hybrydowego. W artykule przedstawiono propozycję budowy nasypu hybrydowego z wykorzystaniem wzmocnienia podobnego do naturalnego procesu biogeochemicznej (węglanowej) diagenezy. Korpus nasypu hybrydowego stanowi grunt słaby z poziomymi wkładkami i kolumnami z piasku wzmocnionego cementacją węglanową wywołaną działaniem drobnoustrojów. Piasek w poziomych wkładkach i kolumnach jest wzmocniony kalcytem magnezowym lub dolomitem wytworzonym przez drobnoustroje ureolityczne. W celu zaprojektowania i zbudowania hybrydowego nasypu omówiono problemy związane ze statecznością nasypu i wykonaniem jego wzmocnienia. Wykazano, że nasyp hybrydowy jest przyjazny 
środowisku i może przyczynić się do rozwiązania problemów technicznych i finansowych napotykanych przy wykorzystaniu gruntów słabych do budowy nasypów.

Slowa kluczowe: nasyp, grunt słaby, piasek w poziomych wkładach, kolumny piaskowe, biocement

\section{MS. received May 2015}

\section{Authors' addresses:}

Masaharu Fukue

Tokai University

974-18 Mabase, Shimizu-ku, Shizuoka, Japan

e-mail: fukue@scc.u-tokai.ac.jp
Zbigniew Lechowicz

Katedra Geoinżynierii

Wydział Budownictwa i Inżynierii Środowiska

SGGW

02-776 Warszawa, ul. Nowoursynowska 159

Poland

e-mail: zbigniew_lechowicz@sggw.pl

Rie Takahashi

Japanese Geotechnical Association for Housing Disaster Prevention

600-6 Ikeda, Suruga-ku, Shzioka, Japan 422-8005

e-mail: Takuchi-bousai@swan.ocn.ne.co

Kouji Uehara

600-6 Ikeda, Suruga-ku, Shizuoka, Japan 422-8005

Life Engineering Co.

e-mail: caster705@yahoo.co.jp 